\title{
Application of Corynebacterium glutamicum engineering display system in three generations of biorefinery
}

Kerui Lin ${ }^{1,2}$, Shuangyan Han ${ }^{1,2}$ and Suiping Zheng ${ }^{1,2^{*}}$ (1)

\begin{abstract}
The fermentation production of platform chemicals in biorefineries is a sustainable alternative to the current petroleum refining process. The natural advantages of Corynebacterium glutamicum in carbon metabolism have led to $C$. glutamicum being used as a microbial cell factory that can use various biomass to produce value-added platform chemicals and polymers. In this review, we discussed the use of $C$. glutamicum surface display engineering bacteria in the three generations of biorefinery resources, and analyzed the C. glutamicum engineering display system in degradation, transport, and metabolic network reconstruction models. These engineering modifications show that the C. glutamicum engineering display system has great potential to become a cell refining factory based on sustainable biomass, and further optimizes the inherent properties of C. glutamicum as a whole-cell biocatalyst. This review will also provide a reference for the direction of future engineering transformation.
\end{abstract}

Keywords: Corynebacterium glutamicum, Surface display system, Biorefinery, Transport, Metabolic network reconstruction

\section{Introduction}

Current industrial chemical products mainly use fossil energy including petroleum, coal, and natural gas as raw materials, and account for about $85 \%$ of energy use $[1,2]$. Fossil resources are not sustainable, and their combustion by-product, carbon dioxide, is the main cause of global warming, accounting for approximately $52 \%$ of global warming factors [3]. The conversion to alternative energy sources from the extraction of fossil fuels leads to a more sustainable economy with renewable resources and has attracted worldwide attention. The utilization of biomass resources provides possibilities for the integrated production of chemistry, materials, energy, and food [4]. The concept of bio-refining emerged and

\footnotetext{
*Correspondence: spzheng@scut.edu.cn

${ }^{1}$ Guangdong Key Laboratory of Fermentation and Enzyme Engineering,

School of Biology and Biological Engineering, South China University of Technology, Guangzhou 510006, People's Republic of China

Full list of author information is available at the end of the article
}

gradually evolved. The biorefining concept is similar to that of traditional petroleum refining and uses biomass as a raw material to obtain a series of products, including commodities, and fine and specialty chemicals [5]. The International Energy Agency (IEA) defines bio-refining as "'the sustainable processing of biomass into a spectrum of marketable products and energy" [6]. Biorefineries have different definitions and classifications according to different conditions, platform technologies, final products, raw materials, and conversion processes. The biorefineries introduced in this review are classified according to the source of the raw materials. Three different types of bio-refineries can be used, depending on whether the raw materials used as raw materials come from starch and other grains (first-generation biorefinery), agricultural waste (second-generation biorefinery), or $\mathrm{CO} 2$ or toxic environmental pollution (third-generation biorefinery) [5, 7-10].In addition, industrial biorefineries have been original author(s) and the source, provide a link to the Creative Commons licence, and indicate if changes were made. The images or other third party material in this article are included in the article's Creative Commons licence, unless indicated otherwise in a credit line to the material. If material is not included in the article's Creative Commons licence and your intended use is not permitted by statutory regulation or exceeds the permitted use, you will need to obtain permission directly from the copyright holder. To view a copy of this licence, visit http://creativecommons.org/licenses/by/4.0/. The Creative Commons Public Domain Dedication waiver (http://creativeco mmons.org/publicdomain/zero/1.0/) applies to the data made available in this article, unless otherwise stated in a credit line to the data. 
identified as the most promising route to the creation of a new domestic bio-based industry [11].

At present, a variety of compounds and commodities are produced through biorefinery. Industrial microorganisms such as Escherichia coli, Saccharomyces cerevisiae, and Corynebacterium glutamicum are designed as microbial cell factories that can use biomass to produce value-added platform chemicals and polymers. Compared with E. coli and S. cerevisiae [12], C. glutamicum has shown great potential to surpass other industrial microorganisms and has many advantages. First, C. glutamicum has low extracellular protease activity and can secrete properly folded functional precursor proteins [13]. Second, C. glutamicum has a weak carbon catabolite inhibitory effect and can use mixed sugars as a carbon source without significant growth retardation [14, 15]. Third, C. glutamicum is robust and exhibits tolerance to organic acids, furfural, and toxic aromatic compounds. Moreover, C. glutamicum cells maintain a strong catalytic function under growth-inhibiting conditions and maintain high cell growth with high-density fermentation [16-18]. These features are of great significance to the toxic substances produced during lignocellulose treatment and environmental pollutant degradation.
Fourth, C. glutamicum has a wide spectrum of natural carbon source substrates. It has a natural metabolic network for five-carbon sugars (D-xylose and L-arabinose), six-carbon sugars (glucose, and mannose), monosaccharides (maltose), and toxic aromatic compounds [19, 20]. The spectrum of C. glutamicum substrates involves three generations of bio-refining raw materials. Additionally, C. glutamicum is safe, has a clear genetic manipulation background, can be used to produce a variety of compounds, and can convert cheap biomass into high-value products.

The direct application of C. glutamicum in biorefineries is limited because it cannot secrete effective hydrolytic enzymes to utilize the biorefinery raw materials. To address this limitation, C. glutamicum has been engineered to optimize and construct the degradation module (consisting of the anchor protein and display enzyme), the transport module (pentose, hexose, and other transporters), and utilization module (natural metabolic network and artificial metabolic network) to perform biological treatment of biomass raw materials and compound production by expressing and displaying various functional genes (Fig. 1). These engineering technologies have expanded the C. glutamicum substrate

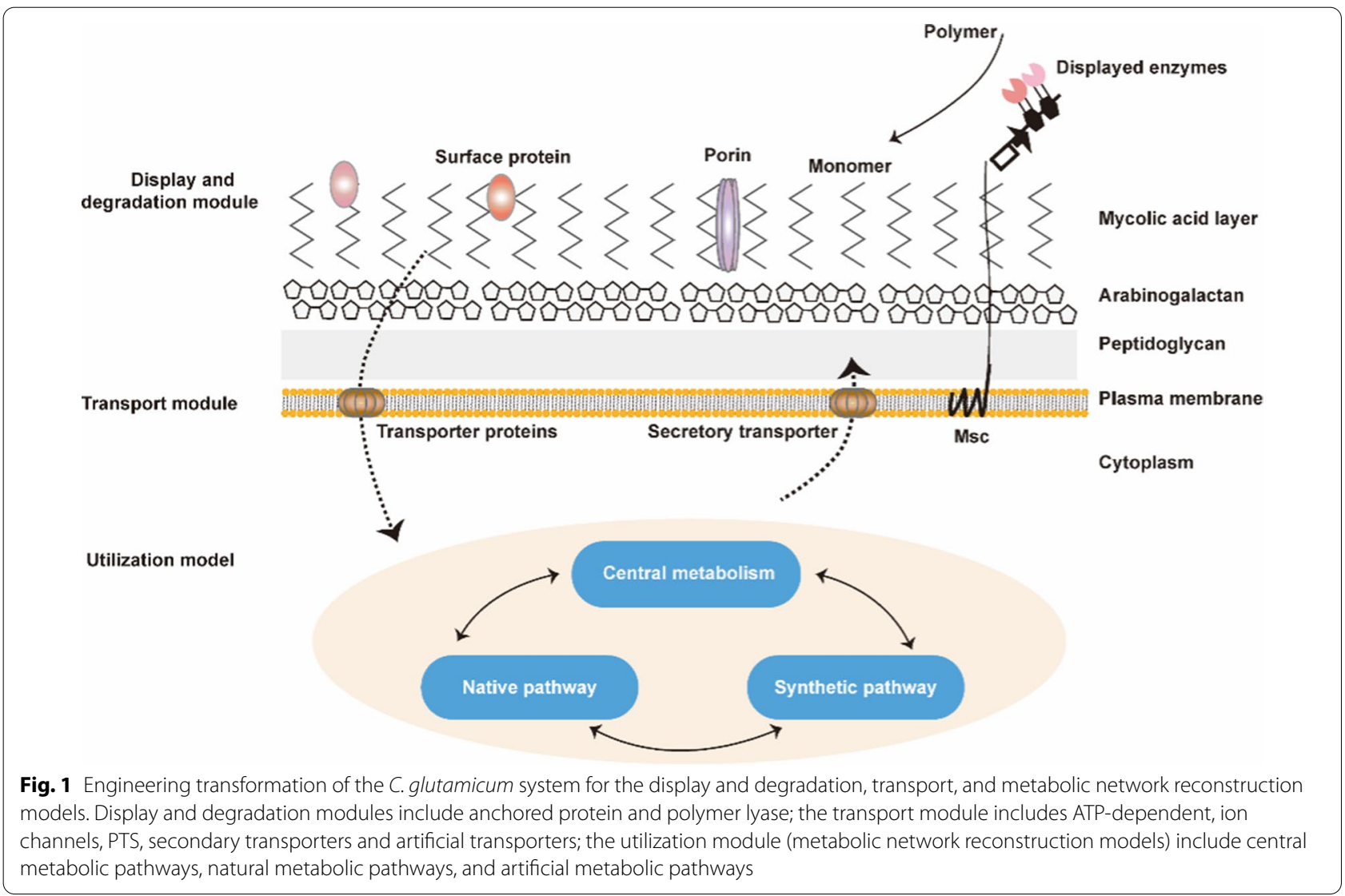


spectrum, enhanced its utilization of renewable biomass resources, and have provided important incremental improvements to the economics of industrial-scale manufacturing (Fig. 1). C. glutamicum will use renewable resources to produce natural or non-natural products, making it a biorefinery cell factory with economic benefits and prospects.

\section{C. glutamicum and its engineering display system}

C. glutamicum is a fast-growing, aerobic, and non-pathogenic Gram-positive soil bacterium that is a generally considered safe (GRAS) industrial microorganism. C. glutamicum has been studied for over 50 years [21]. In the food and feed industries, C. glutamicum is the main production strain of amino acids such as glutamic acid and lysine $[22,23]$, and it has been engineered to produce industrial and commercial chemicals. For example, biofuels (such as ethanol, isobutanol, and higher alcohols), organic acids (such as lactic acid, pyruvic acid, succinic acid, glutaric acid, $\gamma$-aminobutyric acid, methyl salicylic acid, and 5-aminovaleric acid [24-26]), and monomers or precursors for biopolymers (including lactate, succinate, putrescine (1,4-Diaminobutane), cadaverine (1,5-diaminopentane), adipic acid, terephthalic acid, 1,2-propanediol, 4-hydroxybenzoic acid (4-HBA), and 1-(2, 4,6-trihydroxyphenyl)butane-1,3-dione (TPBD) [27-31]) and other high value-added compounds such as resveratrol [16, 32-34]. Additionally, the lack of endotoxin and low extracellular protease content, make C. glutamicum a potential host for the production of recombinant proteins, including pharmaceutical proteins (single-chain Fv $[35,36]$ and Fab fragment [37]) and industrial enzymes (amylase [38-42], glycosidase [43, 44], etc.). Metabolic engineers have been exploring alternative renewable carbon sources that have competitive value in the food and feed industries for the production of commercial chemicals of C. glutamicum (Table 1).

However, surface display technology gives C. glutamicum the ability to utilize renewable carbon sources because the display of functional proteins on the cell surface gives host cells new functions to produce chemicals from cheap biomass [45]. Compared with secreted enzymes, the displayed enzymes have many advantages, including improved stability of enzyme activity [46, 47] and enzyme thermal stability [48], convenient recovery [49] and wide application value (whole cell catalysis, combinatorial library screening, protein engineering, bioremediation, biosensor, biofuels production, etc.) [50-53]. To display proteins on the surface of C. glutamicum, several anchoring motifs have been used. At present, the display system of C. glutamicum only uses three types of anchoring proteins: foreign proteins PgsA, mycoloylated proteins, and membrane proteins. PgsA is a transmembrane protein derived from Bacillus subtilis and is part of the poly- $\gamma$-glutamate synthase complex [42]. Mycoloylated proteins are special proteins that exist on the mycolic acid layer of the C. glutamicum outer membrane and are fixed on mycolic acids through O-acylation covalent modification, which occurs on serine residues [54]. The currently known mycoloylated proteins that can be used as anchor motifs are NCgl1337, ion-selective channel protein NCgl0933 (porin B, PorB), $\mathrm{NCgl0932}$ (porin $\mathrm{C}$, PorC), and $\mathrm{PorH}(\mathrm{NCgl}$ number of PorH have not been assigned [55]) [39, 40]. PorH combines with PorA to form a cation-selective channel called the PorHA channel. In the absence of PorHA channels, a functional anion-selective channel, PorB, is necessary for optimal growth [56]. Among the C. glutamicum membrane proteins, only NCgl1221 (mechanosensitive channel, MscCG) has been developed as an anchor protein[41]. NCgl1221 is also the main glutamate efflux system of C. glutamicum [57]. Recombinant C. glutamicum, with these anchored proteins, has been modified to display carbohydrate-active enzymes (CAZy) to expand the carbon sources available during fermentation and to enable $C$. glutamicum to ferment cheap raw materials into valuable biological products. These CAZy include amylase [38-42], glucanase [58], glycosidase [43, 44], and cellulase complex [59].

C. glutamicum uptake of some of the display system degradation products requires the transport system. The transmembrane transport system in C. glutamicum includes ATP-dependent ion channels, the phosphotransferase system (PTS), and secondary transporters $[29,60,61]$. The transport of many hexoses is involved in the phosphorylation cycle of the PTS system [62]. Pts are composed of two common energy-coupling cytoplasmic proteins, enzyme I (EI) and histidinecontaining phosphor carrier protein $(\mathrm{HPr})$, which are encoded by ptsI (NCgl1858) and ptsH (NCgl1862), respectively, and a series of sugar-specific enzyme II complexes (EII) [63-65]. Currently, four sets of PTSs have been identified in C. glutamicum, each of these PTSs is specific for a different substrate and those identified are specific for glucose, fructose, sucrose, and an unknown substrate [66]. In addition, C. glutamicum can also transport glucose through inositol transporters coded by iolT1 and iolT2 [67]. For aromatic compound transport, most of the functionally identified aromatic compound transport systems belong to either the aromatic acid/H + symporter (AAHS) family of transporters within the major facilitator superfamily (MFS) or the ATP-binding cassette (ABC) superfamily [68]. In $C$. glutamicum, two benzoate transporters are encoded by NCgl2325 and NCgl2326. Additionally, a gene encoding a putative phenylacetate transporter (CgR_0643, 
$\mathrm{NCgl}$ numbers have not been assigned) was observed in the putative paa cluster of C. glutamicum strain R [69]. With the expansion of the substrates of C. glutamicum, artificial transport systems for various substrates have been developed through gene editing (Fig. 2), and a series of methods have been developed for C. glutamicum through reconstruction and optimization of metabolic pathways. In addition, through restructuring and optimizing metabolic pathways, a series of methods have been developed for the uptake, transport, metabolism, and production of the biomass carbon source in C. glutamicum. In the next section, this review will introduce the use of engineering C. glutamicum based on the surface display system in the three generations biorefining raw materials and the engineering transformation in this process (Fig. 2).

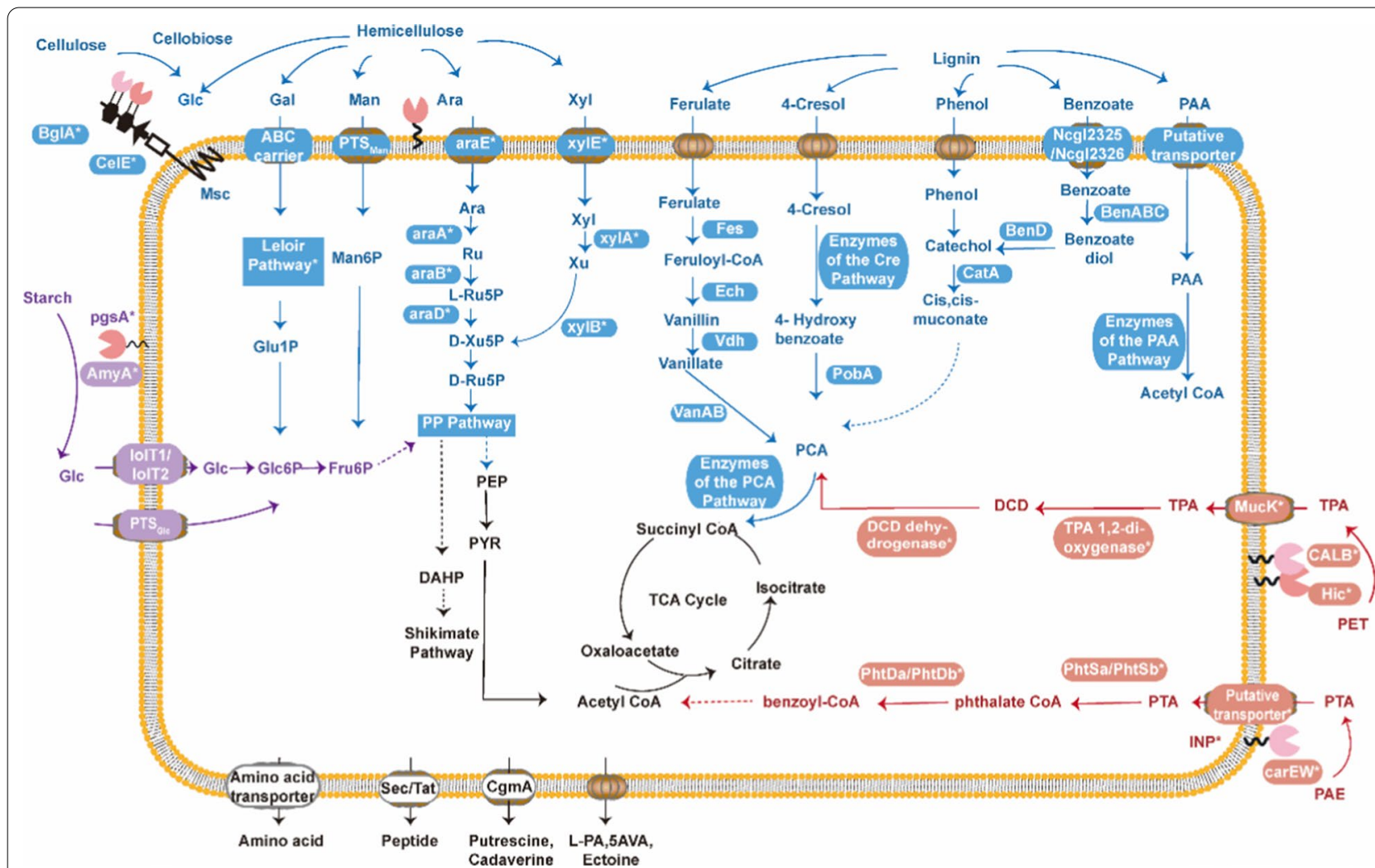

Fig. 2 Utilization of three generations of biorefinery materials based on the surface display system of C. glutamicum, including surface display, transporters, and metabolic reactions. Overview of the surface display, transporters, and metabolic reactions in C. glutamicum for uptake and conversion of three generations of biorefinery materials. Black represents the endogenous reaction of $C$. glutamicum, and * represents foreign proteins expressed by heterologous genes. Purple indicates the utilization path of the first-generation of biorefinery, blue indicates the utilization path of the second-generation of biorefinery, and orange indicates the possible utilization path of the third-generation of biorefinery. The solid line represents direct reactions, and the dashed line represents indirect reactions. Enzymes of the Cre pathway: CreHI, CreJEF, CreG, CreC, and CreD; enzymes of the Paa pathway: PaaK, PaaABCDE, PaaG, PaaZ, PaaG/J, PaaF, PaaH, and PaaJ; amino acid transporter: LyaE for L-lysine, L-arginine, L-citrulline; CgmA for L-arginine; YggB: L-glutamate; ThrE for L-threonine, L-serine; BrnEF: L-valine, L-leucine, L-isoleucine, L-methionine. Glc glucose, Glc6P glucose-6-phosphate, Fru6P frucose-6-phosphate, Xyl xylose, Ara, arabinose, CelE endoglucanase E, BglA $\beta$-glucosidase A, Msc mechanosensitive channel, Glc1P, glucose-1-phosphate, F6P fructose-6-phosphate, PYR pyruvate, Gluc6P, gluconate-6-phosphate, Glc6P gluconate-1-phosphate, Man, mannose, Man6P mannose-6-phosphate, Ara arabinose, AraA arabinose isomerase, AraB ribulokinase, AraD ribulose 5-phosphate 4-epimerase, Ru ribulose, L-Ru5P L-ribulose-5-phosphate, D-Ru5P D-ribulose-5-phosphate, PEP phosphoenolpyruvate, DHAP 1,3-dihydroxyacetone phosphate, and PCA protocatechuate. PTS phosphoenolpyruvate phosphotransferase, Xylu5P xylulose-5-phosphate, $D$-Ribo5P ribose-5-phosphate, $X y / x y l o s e, X y / A$ xylose isomerase, $X y \mid B$ xylulokinase, $X u$ xylulose, $P P$ pathway, pentose phosphate pathway, TCA tricarboxylic acid cycle, $V d h$ putative vanillin dehydrogenase gene, vanAB genes encoding subunits $A$ and $B$ of vanillate demethylase, PAA phenylacetic acid, FCs feruloyl-CoA synthetase, Ech enoyl-CoA hydratase/aldolase, PobA 4-hydroxybenzoate 3-hydroxylase (NCgl1032), CatA catechol 1,2-dioxygenase (NCgl2319), BenABC benzoate dioxygenase complex, encoded putatively by NCg|2320, NCg|2321, and NCg|2322, benD 2-hydro-1,2dihydroxybenzoate dehydrogenase (putatively encoded by NCgl2323), MucK a native MFS transporter known to import muconate in ADP1 (from Acinetobacter baylyi), DCD 1,2-dihydroxy-3,5-cyclo-hexadiene-1,4-dicarboxylate 
Application of C. glutamicum and its surface display system in the first-generations of biological refining

The first generation of biorefinery uses starch and other grains as raw materials to produce biofuels and chemicals. Starch is used as the main carbon source for the industrial production of amino acids, but C. glutamicum cannot directly utilize starch [70]. In the past ten years, researchers have realized the direct utilization of starch and product production by $C$. glutamicum by displaying amylase on the surface. Tateno et al. showed that $\alpha$-amylase (from Streptococcus bovis) surface displayed by pgsA produced $6.04 \mathrm{~g} / \mathrm{L}$ lysine [42], $15.5 \pm 1.3 \mathrm{~g} / \mathrm{L}$ glutamic acid [41], poly- $\beta$-hydroxybutyrate (PHB) [71], cadaverine [72], $88.9 \mathrm{~g} / \mathrm{L}$ lactic acid, and $14.0 \mathrm{~g} / \mathrm{L}$ succinic acid [73] (Fig. 2). In addition, mycolic acid layer proteins PorC, NCgl1337, and membrane protein Msc were used as anchoring motifs to display $\alpha$-amylase, and these recombinant strains produced glutamic acid or L-lysine from starch successfully $[39,41,44]$ (Table 1).
Application of C. glutamicum and its surface display system in the second-generation of biorefinery

The first-generation raw material has adverse effects on food prices and the environment $[74,75]$. However, lignocellulose, the main raw material of the second-generation biorefinery, is a complex heteropolymer composed of cellulose, hemicellulose, and lignin that is formed through hydrogen and covalent bonds. It is a complex heteropolymer that can be used to produce biofuels and abundant renewable raw materials for commercial chemicals [76]. Lignocellulose is composed of $40-50 \%$ cellulose, 25-35\% hemicellulose, and 10-20\% lignin [77]. Cellulose is composed of cellobiose, which is a homopolymer of glucose. Hemicellulose is composed of various hexoses (D-glucose, D-mannose, and D-galactose) and pentoses (D-xylose Xyl and L-Arabinose Ara). The total content of pentose sugars in lignocellulose hydrolysates reaches 5-20\% xylose, $1-5 \%$ arabinose, and 10\%-20\% mannose $[78,79]$. Currently, these monomers are utilized

Table 1 Utilization of three generations of biorefinery raw materials based on the surface display system of C. glutamicum

\begin{tabular}{|c|c|c|c|c|c|c|c|c|}
\hline & Substrate & Anchorprotein & Passengerprotein & $\begin{array}{l}\text { Resource } \\
\text { of } \\
\text { passenger } \\
\text { protein }\end{array}$ & Producer & Product & $\begin{array}{l}\text { Titer(g/ } \\
\text { Lmedium) }\end{array}$ & References \\
\hline \multirow{6}{*}{$\begin{array}{l}\text { First } \\
\text { genera- } \\
\text { tion of } \\
\text { biorefin- } \\
\text { ery }\end{array}$} & \multirow[t]{6}{*}{ Starch } & PgsA & a-amylase(AmyA) & $\begin{array}{l}\text { Streptococ- } \\
\text { cusbovis } 148\end{array}$ & ATCC13032 & L-Lysine & 6.04 & $\begin{array}{l}\text { Tateno et al. } \\
{[42]}\end{array}$ \\
\hline & & PgsA & a-amylase(AmyA) & $\begin{array}{l}\text { Streptococ- } \\
\text { cusbovis } 148\end{array}$ & ATCC13032 & Polyhydroxybutyrate(PHB) & $6.4 w t \%$ & $\begin{array}{l}\text { Song et al. } \\
{[47]}\end{array}$ \\
\hline & & PgsA & a-amylase(AmyA) & $\begin{array}{l}\text { Streptococ- } \\
\text { cusbovis } 148\end{array}$ & ATCC13032 & Organic Acids & 107.8 & $\begin{array}{l}\text { Tsuge et al. } \\
{[73]}\end{array}$ \\
\hline & & NCgl1221 & a-amylase(AmyA) & $\begin{array}{l}\text { Streptococ- } \\
\text { cusbovis } 148\end{array}$ & ATCC 13869 & L-glutamate & 19.3 & $\begin{array}{l}\text { Yao et al. } \\
{[41]}\end{array}$ \\
\hline & & NCgl1337S & a-amylase(AmyA) & $\begin{array}{l}\text { Streptococ- } \\
\text { cusbovis } 148\end{array}$ & ATCC 13032 & L-Lysine & 4.39 & $\begin{array}{l}\text { Choi et al. } \\
\text { [39] }\end{array}$ \\
\hline & & NCgl1337 & a-amylase(AmyA) & $\begin{array}{l}\text { Strepto- } \\
\text { myces } \\
\text { coelicolor } \\
\text { A3(2) }\end{array}$ & ATCC13032 & L-Lysine & 1.75 & $\begin{array}{l}\text { Choi et al. } \\
\text { [39] }\end{array}$ \\
\hline \multirow{4}{*}{$\begin{array}{l}\text { Second } \\
\text { genera- } \\
\text { tion of } \\
\text { biorefin- } \\
\text { ery }\end{array}$} & $\begin{array}{l}\text { Xylooligo- } \\
\text { saccha- } \\
\text { rides }\end{array}$ & PorH & $\beta$-xylosidase $(X y l)$ & $\begin{array}{l}\text { Bacillus- } \\
\text { subtilis }\end{array}$ & PIS8 & $\begin{array}{l}\text { 1,5-Diaminopentane(cad } \\
\text { averine) }\end{array}$ & 1.28 & $\begin{array}{l}\text { Imao et al. } \\
{[127]}\end{array}$ \\
\hline & $\begin{array}{l}\text { Hemicel- } \\
\text { lulose }\end{array}$ & $\begin{array}{l}\text { NCgl1337/ } \\
\text { NCgl1337S }\end{array}$ & Endoxylanase(XInA) & $\begin{array}{l}\text { Strepto- } \\
\text { myces } \\
\text { coelicolor } \\
\text { A3(2) }\end{array}$ & ATCC13032 & Xylooligomers & - & $\begin{array}{l}\text { Choi et al. } \\
\text { [39] }\end{array}$ \\
\hline & \multirow[t]{2}{*}{ Cellobiose } & Porin(porC) & ß-glucosidase(Sde1394) & $\begin{array}{l}\text { Saccha- } \\
\text { rophagus- } \\
\text { degradans }\end{array}$ & ATCC 13032 & L-Lysine & 1.08 & $\begin{array}{l}\text { Adachi et al. } \\
\text { [44] }\end{array}$ \\
\hline & & Porin(porC) & ß-glucosidase(Sde1394) & $\begin{array}{l}\text { Saccha- } \\
\text { rophagus- } \\
\text { degradans }\end{array}$ & $D M 1729$ & L-Lysine & 0.73 & $\begin{array}{l}\text { Anusree } \\
\text { et al. [58] }\end{array}$ \\
\hline $\begin{array}{l}\text { Third } \\
\text { genera- } \\
\text { tion of } \\
\text { biorefin- } \\
\text { ery }\end{array}$ & $\mathrm{CO}_{2}$ & Porin(porB) & carbonic anhydrase (CA) & $\begin{array}{l}\text { Neisseria } \\
\text { gonor- } \\
\text { rhoeae }\end{array}$ & $\begin{array}{l}\text { C.glutami- } \\
\text { cum }\end{array}$ & Bicarbonates & - & $\begin{array}{l}\text { Koo et al. } \\
{[111]}\end{array}$ \\
\hline
\end{tabular}


in C. glutamicum through natural or engineered metabolic networks. Utilizing the natural ability of C. glutamicum to degrade and utilize different sugars, establish effective sugar degradation and transport pathways. This further improves the conversion efficiency of renewable resources and avoids competition between biorefineries and food or feed supplies.

\section{Cellulose}

Cellobiose is a disaccharide composed of two glucose monomers connected with $\beta$-1-4-glycosidic bonds. The degradation of cellulose is generally carried out by a combination of a variety of cellulase enzymes, such as endo $\beta$-1,4-glucanase (EC 3.2.1.4), exo- $\beta$-1,4-glucanase, cellobiohydrolase (EC 3.2.1.91), or $\beta$-glucosidase (BGL) (EC 3.2.1.21). Kim used Msc to display the cellulase complex endoglucanase $E(\mathrm{CelE})$ and $\beta$-glucosidase $\mathrm{A}(\mathrm{BglA})$ enzymes on the $C$. glutamicum cell surface to completely degrade cellulose into glucose. The synergistic effect of these two cellulases significantly improved the saccharification efficiency and thermal stability. The activity of the displayed cellulase complex was higher than that of the secreted cellulase complex [59]. Adachi used porins to display Sde1394 (a BGL from Saccharophagus degradans) on the surface of $C$. glutamicum cells and to directly assimilate cellobiose as a carbon source. The recombinant strain produced $1.08 \mathrm{~g} / \mathrm{L}$ of L-lysine from $20 \mathrm{~g} / \mathrm{L}$ of cellobiose, which was approximately three times higher than the L-lysine produced by secreted BGL in C. glutamicum [44]. In addition, by co-expressing these CAZy in C. glutamicum, glucose, xylose, and arabinose produced by lignocellulose can be used together, and the products produced do not inhibit enzyme activity. The combined utilization of these polysaccharides is of great significance for the practical industrial application of lignocellulose [58, 80, 81]. Shortly, this surface display of multiple enzymes on a single cell will greatly promote whole-cell catalysis [49]. The combined utilization of these polysaccharides is of great significance for the practical industrial application of lignocellulose [58, 81].

\section{Hemicellulose}

The utilization of hemicellulose by C. glutamicum mainly focuses on the transport of hemicellulose hydrolysates, and there are few studies on display involved. Hydrolyzed hemicellulose produces hexoses (D-glucose, D-mannose, and D-galactose) which are transported into the cell through the PTS transport system [29] or the ABC carrier [82] (Fig. 2). Glucose is transported by PTS and produces Glc6P or is transported by lolT1/lolT2 and then converted to Glc6P by hexokinase before entering the glycolytic pathway. The mannose 6-phosphate produced by PTS transport of mannose is reversibly converted to fructose 6-phosphate by the phosphate isomerase(Pmi) before entering glycolysis. As for galactose, wild-type C. glutamicum lacks the galactose metabolism network. The engineered C. glutamicum containing L. lactis subsp. cremoris MG1363 galactose operon, including aldose-1-epimerase ( galM), galactokinase (galK), udpglucose-1-p-Glutamate strains with uridyltransferase (galT), and UDP-galactose-4-epimerase (galE) genes, can grow and produce lysine with galactose as the sole carbon source [83].

At present, the research on the utilization of the hemicellulose products of $C$. glutamicum is mainly xylose and arabinose. Most wild-type C. glutamicum lack effective xylose and arabinose transport or metabolic pathways. Currently, three transmembrane proteins that transport xylose have been used in C. glutamicum: lolT1 [84], XylE [85], and AraE [86]. Most studies on C. glutamicum Xylose metabolism have focused on the xylose isomerase (XI) pathway and the Weimberg (WMB) pathway. Researchers have expressed that $x y l A$ (xylose isomerase) and $x y l B$ (xylose kinase) (from E. coli and Xanthomonas campestris) can utilize D-xylose and produce L-ornithine, lactic acid, and succinic acid in C. glutamicum [87, 88]. Imao et al. used PorH ankyrin to display $\beta$-xylosidase (from B. subtilis) on the cell surface of $C$. glutamicum, and expressed xylAB (from E. coli). The engineered strain could produce $12.4 \mathrm{mM}$ lysine and $11.6 \mathrm{mM}$ 1,5-diaminopentane from $11.9 \mathrm{~g} / \mathrm{L}$ xylo-oligosaccharides. Jin et al. used engineered C. glutamicum GJ04 to produce $61.7 \mathrm{~g} / \mathrm{L}$ glutamic acid from xylose and glucose derived from lignocellulose. Additionally, most wild-type C. glutamicum lack the arabinose transport pathway as well, and a few species of C. glutamicum, such as C. glutamicum ATCC 31831, have the endogenous AraE arabinose transporter [19]. AraE is a membrane channel protein with xylose transport function, which can simultaneously transport L-arabinose. Arabinose is converted into D-xylose5-phosphate by the action of arabinose isomerase (araA), ribonucleic acid kinase (araB), and ribulose-5-phosphate 4-epimerase ( $\mathrm{araD}$ ) to enter the PP pathway. However, because hydrolyzed cellulose is composed of glucose, xylose, arabinose, and other sugars, it can be considered that the fermentation of mixed sugars is the main bottleneck for its utilization [89].

\section{Lignin}

Lignin is composed of coniferyl alcohol, sinapyl alcohol, and p-coumarol benzyl alcohol units, and can be used for the production of aromatic-derived fuels and chemicals [90]. Unfortunately, the complex chemical structure of lignin is a raw material that is difficult to depolymerize and degrade. Lignin decomposition products are mainly aromatic compounds, which are 
usually toxic to microorganisms commonly used in biological production. C. glutamicum can not only tolerate and degrade aromatic hydrocarbons, but can also use many aromatic compounds derived from lignin (including ferulic acid, vanillin, phenol, benzoic acid, phenylacetic acid, and 4-cresol) as the only carbon source for growth and energy [91]. C. glutamicum has a remarkable ability to utilize aromatic compounds, which makes it unique advantages in the use of lignocellulose hydrolysates in industrial fermentation. Becker et al. engineered $C$. glutamicum to produce Cis, cis-muconic acid (MA) from glucose, catechol, phenol, and benzoic acid. After hydrothermal depolymerization of softwood lignin into small aromatic hydrocarbons, the strain accumulated $1.8 \mathrm{~g} / \mathrm{L}$ MA from the hydrolysate [92]. Kallscheuer et al. studied the degradation pathway of ferulic acid in C. glutamicum and expressed genes encoding chalcone synthase (CHS) and chalcone isomerase (CHI), and produced naringenin and mustard caffeic acid from phenylalanine p-coumaric acid and phenylalanine. In addition, the research team knocked out 27 genes of $C$. glutamicum, eliminating most of the catabolism pathways of known aromatic compounds. The resulting strain produces 2-hydroxybenzoate, 3-hydroxybenzoate, protocatechuate, and 4-hydroxybenzoate from intermediates of aromatic amino acids in the shikimate pathway [33, 93, 94].

The high tolerance of $\mathrm{C}$. glutamicum to aromatic compounds may be due to its typical outer membranelike structure (mycomembrane), which is mainly composed of fungal acids and can act as a permeation barrier to toxic aromatic compounds [95]. However, the high resistance to aromatic compounds and complex catabolic network also prevents the metabolism and production of $\mathrm{C}$. glutamicum during the production of aromatic compounds (except aromatic amino acids). This prevents C. glutamicum from being used as a medicine or being used as a production host of aromatic compounds involved in biotechnology [69, 93]. At present, researchers have realized the utilization of lignin hydrolysate and product production through engineering transformation of C. glutamicum, but few display technologies of $C$. glutamicum used in the degradation of lignin polymers. This may be due to the limitation caused by the low expression of the foreign protein of C. glutamicum. In this review, we described the metabolism and regulation of C. glutamicum genes involved in the metabolism of lignin-derived aromatic compounds. It is expected that the display technology of C. glutamicum is a feasible direction for lignin degradation and utilization (Fig. 2) $[18,96-101]$
Application of C. glutamicum and its surface display system in the third-generation of biorefinery

The third-generation biorefinery relies on the use of toxic waste, syngas, microalgae, or bacteria that use sunlight for production. The second-and third-generation biorefineries will reduce the cost of raw material processing, reduce the demand for resources such as food and water, further promote sustainable clean and green biological manufacturing [5, 7]. Corynebacteria are soil and saprophytic microorganisms with cold-tolerant cell walls and have been used in various bioremediation fields. The $C$. glutamicum has a high tolerance to the polymer units of petroleum pollutants, plastics, and pesticides and possesses a natural metabolic network. There are also potential high-yielding strains of these units. Current research mostly focuses on the utilization of C. glutamicum in the decomposition unit of these pollutants, and there is little research about the surface display system. However, the decomposition of polymer pollutants is generally based on chemical decomposition, and it is expected that degradation through demonstration technology is a feasible future direction. Therefore, we mainly discuss progress in the utilization of C. glutamicum for environmental pollutants such as petroleum pollutants, plastics, pesticides, and their derivatives, as well as possible surface display solutions. It is expected that C. glutamicum is a potential bacterial substrate for use in future bioremediation.

The main components of most petroleum pollutants, plastics, and pesticides are aromatic compounds. C. glutamicum can degrade a variety of aromatic monomers. C. glutamicum has a metabolic network involving the following aromatic compounds: benzoic acid, phenol, 3-hydroxybenzoic acid, gentisic acid, protocatechuic acid, vanillic acid, p-hydroxybenzoic acid, 4-cresol, resorcinol, benzyl alcohol, 2,4-dihydroxybenzoic acid, 3,5-dihydroxytoluic acid, naphthalene, vanillin, ferulic acid, cinnamic acid, caffeic acid, and coumaric acid [69] (Fig. 2). C. glutamicum is highly resistant to various toxic aromatic compounds such as phenol, protocatechuic acid, 4-HBA, and 4-ABA, and this feature of C. glutamicum is not observed in other industrial microorganisms including E. coli and B. subtilis. The high tolerance of $C$. glutamicum to toxic aromatic compounds is a key factor in the production of high-valence aromatic compounds. However, most industrially important aromatic compounds are produced through the chemical conversion of petroleum-based raw materials, such as benzene, toluene, and xylene. Therefore, C. glutamicum can connect the degradation of environmental pollutants with the production of commercial plastics, ensuring sustainable green development and avoiding the fossil route [102].

In terms of display technology, researchers have achieved the degradation of aromatic polymers by 
displaying functional enzymes on the surface of yeast. Chen et al. used GPI-modified cell wall proteins to display PETase(polyethylene terephthalate-degrading enzyme) on the surface of Pichia pastoris cells to achieve high-efficiency biodegradation of PET(polyethylene terephthalate) and improve the $\mathrm{pH}$ and thermal stability [102]. Ding et al. displayed the carboxylesterase CarEW (from Bacillus sp. K91) and GFP on the surface of $E$. coli through ice nucleation protein. They found that $1.5 \mathrm{mg} / \mathrm{ml}$ of DiBP (diisobutyl phthalate, one of the main PAE(phthalic acid esters) plasticizers) was degraded by $10 \mathrm{U}$ of surface-displayed CarEW cells in 120 min [103]. In addition, PET and PAE degradation systems, and their monomeric terephthalic acid and phthalic acid transport systems [104-108], and metabolic networks [100, 109] are gradually improving, making it feasible for the application of C. glutamicum display system in these polymers. Therefore, this review envisages the possible PET and PAE degradation pathways in the C. glutamicum display system (Fig. 2).

Researchers recently proposed the concept of $\mathrm{CO}_{2}$ substrate-based third-generation biorefinery for green biomanufacturing $[5,7-10,110]$. C. glutamicum is used in a large number of industrial applications due to its large-scale production process and transgenic stability, and it is a feasible research direction in the capture and application of $\mathrm{CO} 2$. Koo et al. used porB to display carbonic anhydrase (CA) on the surface of $C$. glutamicum to achieve effective $\mathrm{CO} 2$ capture and $\mathrm{CO} 2$ hydrate [111]. In addition, Researchers have used combined biological treatment to utilize $\mathrm{CO}_{2}$-fixed biomass in engineered $C$. glutamicum. Lee et al. used engineered C. glutamicum bacteria and microalgae to jointly process succinic acid production. The engineered strain that secretes amylase can produce succinic acid $(0.28 \mathrm{~g}$ succinic acid/g total sugars including starch) from the pretreated Chlamydomonas reinhardtii microalgae biomass, which is a mixture of starch and glucose accumulated by microalgae grown with $\mathrm{CO}_{2}$ [112]. At present, the Calvin-Benson cycle has been reconstructed in E. coli [113] and Pichia pastoris $[114,115]$ to use $\mathrm{CO}_{2}$ as the only carbon source. Based on the carbon metabolism network and carbon loss advantages of C. glutamicum, it is expected that the use of $\mathrm{CO}_{2}$ for biological manufacturing by C. glutamicum will be a feasible research direction soon.

\section{Challenges and prospects}

C. glutamicum provides a flexible protein production technology platform with a relatively complete display, transport, metabolism, and secretion systems. In addition, many techniques for producing chemicals using sustainable biomass raw materials have been reported through the surface display system of C. glutamicum.
This shows that the development of the display system will expand the potential applications of surface engineering microorganisms to industrial applications. Using biotechnology, exhibiting and using extracellular enzymes to engineer C. glutamicum as a cell refinery in the future is ideal, but challenging. To realize the potential of C. glutamicum in cell refineries in the future, it is necessary to further optimize the display system of $C$. glutamicum, including the following aspects: (1)The display system of Corynebacterium requires optimization to improve the efficiency. Bacterial protein displays have not been widely used in industrial environments, partly because it limits the number and stability of display proteins [116]. (2) Improve the expression level of foreign proteins, optimize the transportation and coordination of carbon metabolism and nitrogen metabolism network. The low production efficiency of the recombinant protein of C. glutamicum is an urgent problem to be solved in the biorefinery of $C$. glutamicum. The metabolic burden is a phenomenon known in heterologous expression systems. It is due to the overexpression of foreign proteins occupying a large part of the intracellular nutrient flux, which affects the balance of cell metabolism [49]. (3) Improve the study of metabolic regulation mechanisms. C. glutamicum still lacks an in-depth understanding of the basic regulatory principles for the synthesis of central metabolic enzymes under different environmental conditions and their effects on cell growth [117]. In recent years, research on the catalysis and regulation mechanism [118-121] and resistance of aromatic compounds [122], genome simplification, optimization of gene editing tools [123, 124], and research on ribosomal switches [125] and biosensors [126] have gradually increased. With the developments in metabolic engineering, systems biology, and synthetic biology, C. glutamicum will hopefully become a promising and advantageous biorefinery factory.

\section{Acknowledgements} Not applicable.

Authors' contributions

$\mathrm{SZ}$ and $\mathrm{KL}$ conceived and designed the manuscript. KL wrote the manuscript. $\mathrm{SH}$ revised the manuscript. All authors read and approved the manuscript.

\section{Funding}

This study was funded by Tianjin Synthetic Biotechnology Innovation Capacity Improvement Project (TSBICIP-KJGG-005) and the National Key R\&D Program of China (Grant No. 2018YFA0901700).

Availability of data and materials

Not applicable.

\section{Declarations}

Ethics approval and consent to participate Not applicable. 


\section{Consent for publication \\ Not applicable.}

\section{Competing interests}

The authors declare that they have no competing interests.

\begin{abstract}
Author details
${ }^{1}$ Guangdong Key Laboratory of Fermentation and Enzyme Engineering, School of Biology and Biological Engineering, South China University of Technology, Guangzhou 510006, People's Republic of China. ${ }^{2}$ Guangdong Research Center of Industrial Enzyme and Green Manufacturing Technology, School of Biology and Biological Engineering, South China University of Technology, Guangzhou 510006, People's Republic of China.
\end{abstract}

Received: 16 July 2021 Accepted: 9 January 2022

Published online: 28 January 2022

\section{References}

1. J Goldemberg 2007 Ethanol for a sustainable energy future Science 315 808810 https://doi.org/10.1126/science.1137013

2. MI Hoffert K Caldeira G Benford DR Criswell C Green H Herzog 2002 Advanced technology paths to global climate stability: energy for a greenhouse planet Science 298981987 https://doi.org/10.1126/scien ce. 1072357

3. TJ Wilbanks SJ Fernandez 2014 Climate change and infrastructure, urban systems, and vulnerabilities: Technical Report for the U.S. Department of Energy in Support of the National Climate Assessment Island Press Washington

4. MA Torres Manno MD Pizarro M Prunello C Magni LD Daurelio M Espariz 2019 GeM-Pro: a tool for genome functional mining and microbial profiling Appl Microbiol Biotechnol https://doi.org/10.1007/ s00253-019-09648-8

5. Castilla-Archilla J, O'Flaherty V, Lens PNL. Biorefineries: Industrial Innovation and Tendencies. In: Bastidas-Oyanedel J-R, Schmidt JE, editors. Biorefinery: Integrated sustainable processes for biomass conversion to biomaterials, biofuels, and fertilizers /Juan-Rodrigo Bastidas-Oyanedel, Jens Ejbye Schmidt, editors. Cham, Switzerland: Springer; 2019. p. 3-35. https://doi.org/10.1007/978-3-030-10961-5_1.

6. de Jong E, Higson A, Walsh P, Wellisch M. Task 42 Biobased Chemicals - Value Added Products from Biorefineries. Available from: http:// www.qibebt.ac.cn/xwzx/kydt/201202/P020120223409482956847. pdf nhttp://www.ieabioenergy.com/publications/ bio-based-chemicals-value-added-products-from-biorefineries/

7. Z Liu K Wang Y Chen TTan J Nielsen 2020 Third-generation biorefineries as the means to produce fuels and chemicals from CO 2 Nat Catal 3274 288 https://doi.org/10.1038/s41929-019-0421-5

8. Hossain GS, Liu L, Du GC. Industrial Bioprocesses and the Biorefinery Concept. In: Larroche C, Sanroman MA, Du G, Pandey A, editors. Current developments in biotechnology and bioengineering: Bioprocesses, bioreactors and controls / edited by Christian Larroche, M. Angeles Sanroman, Guocheng Du, Ashok Pandey. Amsterdam: Elsevier; 2016. p. 3-27. https://doi.org/10.1016/B978-0-444-63663-8.00001-X.

9. Z Liu K Wang Y Chen TTan J Nielsen 2020 Third-generation biorefineries as the means to produce fuels and chemicals from CO2 Nat Catal 3274 288 https://doi.org/10.1038/s41929-019-0421-5

10. J Moncada CA Cardona LE Rincón 2015 Design and analysis of a second and third generation biorefinery: the case of castorbean and microalgae Bioresour Technol 198836843 https://doi.org/10.1016/j.biortech. 2015.09.077

11. B Kamm PR Gruber M Kamm 2006 Biorefineries-industrial processes and products Wiley-VCH Weinheim

12. JT Arnone 2020 Genomic considerations for the modification of Saccharomyces cerevisiae for biofuel and metabolite biosynthesis Microorganisms https://doi.org/10.3390/microorganisms8030321

13. X Liu Y Yang W Zhang Y Sun F Peng L Jeffrey 2016 Expression of recombinant protein using Corynebacterium glutamicum: progress, challenges and applications Crit Rev Biotechnol 36652664 https://doi.org/10. 3109/07388551.2015.1004519
14. A Burkovski 2008 Corynebacteria: Genomics and molecular biology Caister Academic Wymondham

15. KAG Baritugo HT Kim YC David JH Choi J Choi TW Kim 2018 Recent advances in metabolic engineering of Corynebacterium glutamicum as a potential platform microorganism for biorefinery Biofuels Bioprod Bioref 12899925 https://doi.org/10.1002/bbb.1895

16. T Kogure M Inui 2018 Recent advances in metabolic engineering of Corynebacterium glutamicum for bioproduction of value-added aromatic chemicals and natural products Appl Microbiol Biotechnol 102 86858705 https://doi.org/10.1007/s00253-018-9289-6

17. M Conrady A Lemoine MH Limberg M Oldiges P Neubauer S Junne 2019 Carboxylic acid consumption and production by Corynebacterium glutamicum Biotechnol Prog 35 e2804 https://doi.org/10.1002/btpr. 2804

18. C Chen J Pan X Yang H Xiao Y Zhang M Si 2017 Global transcriptomic analysis of the response of Corynebacterium glutamicum to ferulic acid Arch Microbiol 199325334 https://doi.org/10.1007/s00203-016-1306-5

19. JW Choi EJ Jeon KJ Jeong 2019 Recent advances in engineering Corynebacterium glutamicum for utilization of hemicellulosic biomass Curr Opin Biotechnol 571724 https://doi.org/10.1016/j.copbio.2018.11. 004

20. Kitade Y, Hiraga K, Inui M. Aromatic compound catabolism in Corynebacterium glutamicum. In: Corynebacterium glutamicum: Springer. https://doi.org/10.1007/978-3-030-39267-3_11.

21. AA Vertès M Inui H Yukawa 2012 Postgenomic approaches to using corynebacteria as biocatalysts Annu Rev Microbiol 66521550 https:// doi.org/10.1146/annurev-micro-010312-105506

22. J Yang S Yang 2017 Comparative analysis of Corynebacterium glutamicum genomes: a new perspective for the industrial production of amino acids BMC Genomics 18940 https://doi.org/10.1186/ s12864-016-3255-4

23. GS Andriiash OS Sekan OO Tigunova YB Blume SM Shulga 2020 Metabolic engineering of lysine producing Corynebacterium glutamicum strains Cytol Genet 54137146 https://doi.org/10.3103/S009545272 0020024

24. S Kobayashi H Kawaguchi T Shirai K Ninomiya KTakahashi A Kondo Y Tsuge 2020 Automatic redirection of carbon flux between glycolysis and pentose phosphate pathway using an oxygen-responsive metabolic switch in Corynebacterium glutamicum ACS Synth Biol 9814826 https://doi.org/10.1021/acssynbio.9b00493

25. N Kallscheuer H Kage L Milke M Nett J Marienhagen 2019 Microbial synthesis of the type I polyketide 6-methylsalicylate with Corynebacterium glutamicum Appl Microbiol Biotechnol 10396199631 https://doi. org/10.1007/s00253-019-10121-9

26. SWieschalka B Blombach BJ Eikmanns 2012 Engineering Corynebacterium glutamicum for the production of pyruvate Appl Microbiol Biotechnol 94449459 https://doi.org/10.1007/s00253-011-3843-9

27. L Milke N Kallscheuer J Kappelmann J Marienhagen 2019 Tailoring Corynebacterium glutamicum towards increased malonyl-CoA availability for efficient synthesis of the plant pentaketide noreugenin Microb Cell Fact 1871 https://doi.org/10.1186/s12934-019-1117-x

28. SY Lee HU Kim TU Chae JS Cho JW Kim JH Shin 2019 A comprehensive metabolic map for production of bio-based chemicals Nat Catal 21833 https://doi.org/10.1038/s41929-018-0212-4

29. F Pérez-García VF Wendisch 2018 Transport and metabolic engineering of the cell factory Corynebacterium glutamicum FEMS Microbiol Lett https://doi.org/10.1093/femsle/fny166

30. J-Y Lee Y-A Na E Kim H-S Lee P Kim 2016 The actinobacterium Corynebacterium glutamicum, an industrial workhorse J Microbiol Biotechnol 26807822 https://doi.org/10.4014/jmb.1601.01053

31. Y Kitade R Hashimoto M Suda K Hiraga M Inui 2018 Production of 4-hydroxybenzoic acid by an aerobic growth-arrested bioprocess using metabolically engineered Corynebacterium glutamicum Appl Environ Microbiol https://doi.org/10.1128/AEM.02587-17

32. L Milke P Ferreira N Kallscheuer A Braga M Vogt J Kappelmann 2019 Modulation of the central carbon metabolism of Corynebacterium glutamicum improves malonyl-CoA availability and increases plant polyphenol synthesis Biotechnol Bioeng 11613801391 https://doi.org/ 10.1002/bit.26939 
33. N Kallscheuer J Marienhagen 2017 Produktion pflanzlicher Polyphenole mit Corynebacterium glutamicum BIOspektrum 23344346 https://doi. org/10.1007/s12268-017-0804-6

34. N Kallscheuer M Vogt M Bott J Marienhagen 2017 Functional expression of plant-derived O-methyltransferase, flavanone 3-hydroxylase, and flavonol synthase in Corynebacterium glutamicum for production of pterostilbene, kaempferol, and quercetin J Biotechnol 258190196 https://doi.org/10.1016/j.jbiotec.2017.01.006

35. SJ An SS Yim KJ Jeong 2013 Development of a secretion system for the production of heterologous proteins in Corynebacterium glutamicum using the Porin B signal peptide Protein Expr Purif 89251257 https:// doi.org/10.1016/j.pep.2013.04.003

36. SS Yim SJ An JW Choi AJ Ryu KJ Jeong 2013 High-level secretory production of recombinant single-chain variable fragment (scFv) in Corynebacterium glutamicum Appl Microbiol Biotechnol 98273284 https://doi.org/10.1007/s00253-013-5315-x

37. Y Matsuda H Itaya Y Kitahara NM Theresia EA Kutukova YAV Yomantas 2014 Double mutation of cell wall proteins CspB and PBP1a increases secretion of the antibody Fab fragment from Corynebacterium glutamicum Microb Cell Fact 1356 https://doi.org/10.1186/1475-2859-13-56

38. TTateno H Fukuda A Kondo 2007 Direct production of L-lysine from raw corn starch by Corynebacterium glutamicum secreting Streptococcus bovis alpha-amylase using cspB promoter and signal sequence Appl Microbiol Biotechnol 77533541 https://doi.org/10.1007/ s00253-007-1191-6

39. JW Choi SS Yim KJ Jeong 2018 Development of a potential protein display platform in Corynebacterium glutamicum using mycolic acid layer protein, NCgl1337, as an anchoring motif Biotechnol J https://doi. org/10.1002/biot.201700509

40. T Tateno K Hatada T Tanaka H Fukuda A Kondo 2009 Development of novel cell surface display in Corynebacterium glutamicum using porin Appl Microbiol Biotechnol 84733739 https://doi.org/10.1007/ s00253-009-2021-9

41. W Yao C Chu X Deng Y Zhang M Liu P Zheng Z Sun 2009 Display of alpha-amylase on the surface of Corynebacterium glutamicum cells by using NCgl1221 as the anchoring protein, and production of glutamate from starch Arch Microbiol 191751759 https://doi.org/10.1007/ s00203-009-0506-7

42. T Tateno H Fukuda A Kondo 2007 Production of L-Lysine from starch by Corynebacterium glutamicum displaying alpha-amylase on its cell surface Appl Microbiol Biotechnol 7412131220 https://doi.org/10. 1007/s00253-006-0766-y

43. I Muñoz-Gutiérrez R Oropeza G Gosset A Martinez 2012 Cell surface display of a $\beta$-glucosidase employing the type $V$ secretion system on ethanologenic Escherichia coli for the fermentation of cellobiose to ethanol J Ind Microbiol Biotechnol 3911411152 https://doi.org/10. 1007/s10295-012-1122-0

44. N Adachi C Takahashi N Ono-Murota R Yamaguchi TTanaka A Kondo 2013 Direct L-lysine production from cellobiose by Corynebacterium glutamicum displaying beta-glucosidase on its cell surface Appl Microbiol Biotechnol 9771657172 https://doi.org/10.1007/ s00253-013-5009-4

45. TTanaka A Kondo 2015 Cell surface engineering of industrial microorganisms for biorefining applications Biotechnol Adv 3314031411 https://doi.org/10.1016/j.biotechadv.2015.06.002

46. S Yamakawa R Yamada T Tanaka C Ogino A Kondo 2012 Repeated fermentation from raw starch using Saccharomyces cerevisiae displaying both glucoamylase and a-amylase Enzyme Microb Technol 50343347 https://doi.org/10.1016/j.enzmictec.2012.03.005

47. Y Song K Matsumoto T Tanaka A Kondo S Taguchi 2013 Single-step production of polyhydroxybutyrate from starch by using a-amylase cell-surface displaying system of Corynebacterium glutamicum J Biosci Bioeng 1151214 https://doi.org/10.1016/j.jbiosc.2012.08.004

48. W Liu H Zhao B Jia L Xu Y Yan 2010 Surface display of active lipase in Saccharomyces cerevisiae using Cwp2 as an anchor protein Biotech Lett 32255260 https://doi.org/10.1007/s10529-009-0138-7

49. J Schüürmann P Quehl G Festel J Jose 2014 Bacterial whole-cell biocatalysts by surface display of enzymes: toward industrial application Appl Microbiol Biotechnol 9880318046 https://doi.org/10.1007/ s00253-014-5897-y
50. CH Wu A Mulchandani W Chen 2008 Versatile microbial surface-display for environmental remediation and biofuels production Trends Microbiol 16181188 https://doi.org/10.1016/j.tim.2008.01.003

51. A Kondo M Ueda 2004 Yeast cell-surface display-applications of molecular display Appl Microbiol Biotechnol 642840 https://doi.org/ 10.1007/s00253-003-1492-3

52. L Han Y Zhao S Cui B Liang 2018 Redesigning of microbial cell surface and its application to whole-cell biocatalysis and biosensors Appl Biochem Biotechnol 185396418 https://doi.org/10.1007/ s12010-017-2662-6

53. GM Cherf JR Cochran 2015 Applications of yeast surface display for protein engineering Methods Mol Biol 1319155175 https://doi.org/10. 1007/978-1-4939-2748-7_8

54. E Huc X Meniche R Benz N Bayan A Ghazi M Tropis M Daffé 2010 O-mycoloylated proteins from Corynebacterium: an unprecedented post-translational modification in bacteria J Biol Chem 28521908 21912 https://doi.org/10.1074/jbc.C110.133033

55. M Inui KToyoda 2020 Corynebacterium glutamicum: Biology and Biotechnology/edited by Masayuki Inui, Koichi Toyoda 2 Springer Cham

56. H Issa E Huc-Claustre T Reddad N Bonadé Bottino M Tropis C Houssin 2017 Click-chemistry approach to study mycoloylated proteins: Evidence for PorB and PorC porins mycoloylation in Corynebacterium glutamicum PLoS ONE https://doi.org/10.1371/journal.pone.0171955

57. Y Nakayama K-I Hashimoto H Kawasaki B Martinac 2019"Force-FromLipids" mechanosensation in Corynebacterium glutamicum Biophys Rev 11327333 https://doi.org/10.1007/s12551-019-00524-3

58. M Anusree VF Wendisch KM Nampoothiri 2016 Co-expression of endoglucanase and $\beta$-glucosidase in Corynebacterium glutamicum DM1729 towards direct lysine fermentation from cellulose Bioresour Technol 213 239244 https://doi.org/10.1016/j.biortech.2016.03.019

59. SJ Kim JE Hyeon SD Jeon G Choi SO Han 2014 Bi-functional cellulases complexes displayed on the cell surface of Corynebacterium glutamicum increase hydrolysis of lignocelluloses at elevated temperature Enzyme Microb Technol 666773 https://doi.org/10.1016/j.enzmictec. 2014.08.010

60. LDH Elbourne SG Tetu KA Hassan IT Paulsen 2017 TransportDB 2.0: a database for exploring membrane transporters in sequenced genomes from all domains of life Nucleic Acids Res https://doi.org/10.1093/nar/ gkw1068

61. L Eggeling M Bott Eds 2005 Handbook of Corynebacterium glutamicum Taylor \& Francis Boca Raton

62. M Mori I Shiio 1987 Pyruvate formation and sugar metabolism in an amino acid-producing bacterium Brevibacterium flavum Agric Biol Chem 51129138 https://doi.org/10.1080/00021369.1987.10868003

63. N Kuhlmann DP Petrov AW Henrich SN Lindner VF Wendisch GM Seibold 2015 Transcription of malP is subject to phosphotransferase system-dependent regulation in Corynebacterium glutamicum Microbiology 16118301843 https://doi.org/10.1099/mic.0.000134

64. GB Martins G Giacomelli O Goldbeck GM Seibold M Bramkamp 2019 Substrate-dependent cluster density dynamics of Corynebacterium glutamicum phosphotransferase system permeases Mol Microbiol 111 13351354 https://doi.org/10.1111/mmi.14224

65. M lkeda 2012 Sugar transport systems in Corynebacterium glutamicum: features and applications to strain development Appl Microbiol Biotechnol 9611911200 https://doi.org/10.1007/s00253-012-4488-z

66. S Parche A Burkovski GA Sprenger B Weil R Krämer F Titgemeyer 2001 Corynebacterium glutamicum: a dissection of the PTS J Mol Microbiol Biotechnol 3423428

67. M Ikeda Y Mizuno S Awane M Hayashi S Mitsuhashi S Takeno 2011 Identification and application of a different glucose uptake system that functions as an alternative to the phosphotransferase system in Corynebacterium glutamicum Appl Microbiol Biotechnol 9014431451 https://doi.org/10.1007/s00253-011-3210-x

68. PS Phale H Malhotra BA Shah 2020 Degradation strategies and associated regulatory mechanisms/features for aromatic compound metabolism in bacteria Adv Appl Microbiol 112165 https://doi.org/10.1016/bs. aambs.2020.02.002

69. X-H Shen N-Y Zhou S-J Liu 2012 Degradation and assimilation of aromatic compounds by Corynebacterium glutamicum: Another potential for applications for this bacterium? Appl Microbiol Biotechnol 957789 https://doi.org/10.1007/s00253-012-4139-4 
70. G Seibold M Auchter S Berens J Kalinowski BJ Eikmanns 2006 Utilization of soluble starch by a recombinant Corynebacterium glutamicum strain: growth and lysine production J Biotechnol 124381391 https://doi.org/ 10.1016/j.jbiotec.2005.12.027

71. Q Liu S-P Ouyang J Kim G-Q Chen 2007 The impact of PHB accumulation on L-glutamate production by recombinant Corynebacterium glutamicum J Biotechnol 132273279 https://doi.org/10.1016/j.jbiotec. 2007.03.014

72. TTateno Y Okada T Tsuchidate T Tanaka H Fukuda A Kondo 2009 Direct production of cadaverine from soluble starch using Corynebacterium glutamicum coexpressing alpha-amylase and lysine decarboxylase Appl Microbiol Biotechnol 82115121 https://doi.org/10.1007/ s00253-008-1751-4

73. Y Tsuge T Tateno K Sasaki T Hasunuma TTanaka A Kondo 2013 Direct production of organic acids from starch by cell surface-engineered Corynebacterium glutamicum in anaerobic conditions AMB Express 372 https://doi.org/10.1186/2191-0855-3-72

74. Nguyen Q, Bowyer J, Howe J, Bratkovich S, Groot H, Pepke E, Fernholz K (2017) Global production of second generation biofuels: Trends and influences. Dovetail Partners Inc.

75. SN Naik W Goud PK Rout AK Dalai 2010 Production of first and second generation biofuels: A comprehensive review Renew Sustain Energy Rev 14578597 https://doi.org/10.1016/j.rser.2009.10.003

76. FH Isikgor CR Becer 2015 Lignocellulosic biomass: a sustainable platform for the production of bio-based chemicals and polymers Polym Chem 644974559 https://doi.org/10.1039/C5PY00263J

77. D Kaloudas N Pavlova R Penchovsky 2021 Lignocellulose, algal biomass, biofuels and biohydrogen: a review Environ Chem Lett https://doi.org/ 10.1007/s10311-021-01213-y

78. A Aristidou M Pentilla 2000 Metabolic engineering applications to renewable resource utilization Curr Opin Biotechnol 11187198 https:// doi.org/10.1016/S0958-1669(00)00085-9

79. D Peters 2006 Carbohydrates for fermentation Biotechnol J 1806814 https://doi.org/10.1002/biot.200600041

80. M Sasaki T Jojima M Inui H Yukawa 2008 Simultaneous utilization of D-cellobiose, D-glucose, and D-xylose by recombinant Corynebacterium glutamicum under oxygen-deprived conditions Appl Microbiol Biotechnol 81691699 https://doi.org/10.1007/s00253-008-1703-z

81. R Matsuura M Kishida R Konishi Y Hirata N Adachi S Segawa 2019 Metabolic engineering to improve 1,5-diaminopentane production from cellobiose using $\beta$-glucosidase-secreting Corynebacterium glutamicum Biotechnol Bioeng 11626402651 https://doi.org/10.1002/bit.27082

82. AS Santos RT Ramos A Silva R Hirata AL Mattos-Guaraldi R Meyer 2018 Searching whole genome sequences for biochemical identification features of emerging and reemerging pathogenic Corynebacterium species Funct Integr Genomics 18593610 https://doi.org/10.1007/ s10142-018-0610-3

83. E Barrett C Stanton O Zelder G Fitzgerald RP Ross 2004 Heterologous expression of lactose- and galactose-utilizing pathways from lactic acid bacteria in Corynebacterium glutamicum for production of lysine in whey Appl Environ Microbiol 7028612866 https://doi.org/10.1128/ aem.70.5.2861-2866.2004

84. C Brüsseler A Radek N Tenhaef K Krumbach S Noack J Marienhagen 2018 The myo-inositol/proton symporter lolT1 contributes to d-xylose uptake in Corynebacterium glutamicum Bioresour Technol 249953961 https://doi.org/10.1016/j.biortech.2017.10.098

85. SS Yim JW Choi SH Lee KJ Jeong 2016 Modular optimization of a hemicellulose-utilizing pathway in Corynebacterium glutamicum for consolidated bioprocessing of hemicellulosic biomass ACS Synth Biol 5 334343 https://doi.org/10.1021/acssynbio.5b00228

86. Z Chen J Huang Y Wu W Wu Y Zhang D Liu 2017 Metabolic engineering of Corynebacterium glutamicum for the production of 3-hydroxypropionic acid from glucose and xylose Metab Eng 39151158 https://doi. org/10.1016/j.ymben.2016.11.009

87. H Kawaguchi AA Vertès S Okino M Inui H Yukawa 2006 Engineering of a xylose metabolic pathway in Corynebacterium glutamicum Appl Environ Microbiol 7234183428 https://doi.org/10.1128/AEM.72.5.3418-3428. 2006

88. B Zhang Y Jiang Z Li F Wang X-Y Wu 2020 Recent progress on chemical production from non-food renewable feedstocks using
Corynebacterium glutamicum Front Bioeng Biotechnol 8606047 https:// doi.org/10.3389/fbioe.2020.606047

89. M Mindt M Heuser VF Wendisch 2019 Xylose as preferred substrate for sarcosine production by recombinant Corynebacterium glutamicum Bioresour Technol 281135142 https://doi.org/10.1016/j.biortech.2019. 02.084

90. J Becker C Wittmann 2019 A field of dreams: Lignin valorization into chemicals, materials, fuels, and health-care products Biotechnol Adv 37 107360 https://doi.org/10.1016/j.biotechadv.2019.02.016

91. VF Wendisch JMP Jorge F Pérez-García E Sgobba 2016 Updates on industrial production of amino acids using Corynebacterium glutamicum World J Microbiol Biotechnol 32105 https://doi.org/10.1007/ s11274-016-2060-1

92. J Becker M Kuhl M Kohlstedt S Starck C Wittmann 2018 Metabolic engineering of Corynebacterium glutamicum for the production of cis, cis-muconic acid from lignin Microb Cell Fact 17115 https://doi.org/10. 1186/s12934-018-0963-2

93. N Kallscheuer J Marienhagen 2018 Corynebacterium glutamicum as platform for the production of hydroxybenzoic acids Microb Cell Fact $17113 \mathrm{https}: / /$ doi.org/10.1186/s12934-018-0923-x

94. N Kallscheuer M Vogt A Stenzel J Gätgens M Bott J Marienhagen 2016 Construction of a Corynebacterium glutamicum platform strain for the production of stilbenes and (2S)-flavanones Metab Eng 384755 https://doi.org/10.1016/j.ymben.2016.06.003

95. M-A Lanéelle M Tropis M Daffé 2013 Current knowledge on mycolic acids in Corynebacterium glutamicum and their relevance for biotechnological processes Appl Microbiol Biotechnol 9799239930 https:// doi.org/10.1007/s00253-013-5265-3

96. N Kallscheuer M Vogt J Kappelmann K Krumbach S Noack M Bott J Marienhagen 2016 Identification of the phd gene cluster responsible for phenylpropanoid utilization in Corynebacterium glutamicum Appl Microbiol Biotechnol 10018711881 https://doi.org/10.1007/ s00253-015-7165-1

97. H Merkens G Beckers A Wirtz A Burkovski 2005 Vanillate Metabolism in Corynebacterium glutamicum Curr Microbiol 515965 https://doi.org/ 10.1007/s00284-005-4531-8

98. Y Huang K Zhao X-H Shen C-Y Jiang S-J Liu 2008 Genetic and biochemical characterization of a 4-hydroxybenzoate hydroxylase from Corynebacterium glutamicum Appl Microbiol Biotechnol 787583 https://doi.org/10.1007/s00253-007-1286-0

99. W Ding M Si W Zhang Y Zhang C Chen L Zhang 2015 Functional characterization of a vanillin dehydrogenase in Corynebacterium glutamicum Sci Rep 58044 https://doi.org/10.1038/srep08044

100. L Du L Ma F Qi X Zheng C Jiang A Li 2016 Characterization of a unique pathway for 4-cresol catabolism initiated by phosphorylation in Corynebacterium glutamicum J Biol Chem 29165836594 https://doi. org/10.1074/jbc.M115.695320

101. X Shen S Liu 2005 Key enzymes of the protocatechuate branch of the $\beta$-ketoadipate pathway for aromatic degradation inCorynebacterium glutamicum Sci China, Ser C Life Sci 48241249 https://doi.org/10.1007/ BF03183617

102. Z Chen Y Wang Y Cheng X Wang S Tong H Yang Z Wang 2020 Efficient biodegradation of highly crystallized polyethylene terephthalate through cell surface display of bacterial PETase Sci Total Environ 709 136138 https://doi.org/10.1016/j.scitotenv.2019.136138

103. J Ding Y Zhou C Wang Z Peng Y Mu X Tang Z Huang 2020 Development of a whole-cell biocatalyst for diisobutyl phthalate degradation by functional display of a carboxylesterase on the surface of Escherichia coli Microb Cell Fact https://doi.org/10.1186/s12934-020-01373-6

104. A Carniel É Valoni J Nicomedes ADC Gomes AMD Castro 2017 Lipase from Candida antarctica (CALB) and cutinase from Humicola insolens act synergistically for PET hydrolysis to terephthalic acid Process Biochem 598490 https://doi.org/10.1016/j.procbio.2016.07.023

105. A Lykidis C-L Chen SG Tringe AC MCHardy A Copeland NC Kyrpides 2011 Multiple syntrophic interactions in a terephthalate-degrading methanogenic consortium ISME J 5122130 https://doi.org/10.1038/ ismej.2010.125

106. J-H Wu F-Y Wu H-P Chuang W-Y Chen H-J Huang S-H Chen W-T Liu 2013 Community and proteomic analysis of methanogenic consortia degrading terephthalate Appl Environ Microbiol 79105112 https://doi. org/10.1128/AEM.02327-12 
107. SE Nybo NE Khan BM Woolston WR Curtis 2015 Metabolic engineering in chemolithoautotrophic hosts for the production of fuels and chemicals Metab Eng 30105120 https://doi.org/10.1016/j.ymben.2015.04.008

108. I Pardo RK Jha RE Bermel F Bratti M Gaddis E McIntyre 2020 Gene amplification, laboratory evolution, and biosensor screening reveal MucK as a terephthalic acid transporter in Acinetobacter baylyi ADP1 Metab Eng 62260274 https://doi.org/10.1016/j.ymben.2020.09.009

109. HT Kim JK Kim HG Cha MJ Kang HS Lee TU Khang 2019 Biological valorization of poly(ethylene terephthalate) monomers for upcycling waste PET ACS Sustain Chem Eng 71939619406 https://doi.org/10. 1021/acssuschemeng.9b03908

110. PP Peralta-Yahya F Zhang SB Cardayre del JD Keasling 2012 Microbial engineering for the production of advanced biofuels Nature 488320 328 https://doi.org/10.1038/nature1 1478

111. BI Koo JW Choi SY Song YH Choi TY Lee S-H Kim 2021 Robust biocatalysts displayed on crystalline protein-layered cells for efficient and sustainable hydration of carbon dioxide Adv Funct Mater https://doi. org/10.1002/adfm.202102497

112. J Lee SJ Sim M Bott Y Um M-K Oh HM Woo 2014 Succinate production from $\mathrm{CO} 2$-grown microalgal biomass as carbon source using engineered Corynebacterium glutamicum through consolidated bioprocessing Sci Rep 45819 https://doi.org/10.1038/srep05819

113. N Antonovsky S Gleizer E Noor Y Zohar E Herz U Barenholz 2016 Sugar synthesis from CO2 in Escherichia coli Cell 166115125 https://doi.org/ 10.1016/j.cell.2016.05.064

114. T Gassler M Sauer B Gasser M Egermeier C Troyer T Causon 2020 The industrial yeast Pichia pastoris is converted from a heterotroph into an autotroph capable of growth on CO2 Nat Biotechnol 38210216 https://doi.org/10.1038/s41587-019-0363-0

115. Gassler T, Sauer M, Gasser B, et al (2019) A synthetic Calvin cycle enables autotrophic growth in yeast. bioRxiv, 2019: 862599. https://doi.org/10. $1101 / 862599$

116. LH Grace 2017 Bacillus subtilis as a candidate for consolidated bioprocessing: microbial cell wall engineering for the display of heterologous proteins University of California Los Angeles 240

117. S Noack R Voges J Gätgens W Wiechert 2017 The linkage between nutrient supply, intracellular enzyme abundances and bacterial growth: New evidences from the central carbon metabolism of Corynebacterium glutamicum J Biotechnol 2581324 https://doi.org/10.1016/j.jbiot ec.2017.06.407

118. A Aleshintsev E Eppinger JAD Gröning A Stolz R Gupta 2019 Substrate promiscuity and active site differences in gentisate 1,2-dioxygenases: electron paramagnetic resonance study J Biol Inorg Chem 24287296 https://doi.org/10.1007/s00775-019-01646-5

119. C Cai Y Nie Y Gong S Li TA Ramelot MA Kennedy 2020 Solution NMR structure of CGL2373, a polyketide cyclase-like protein from Corynebacterium g/utamicum Proteins 88237241 https://doi.org/10.1002/prot. 25771

120. L Milke M Mutz J Marienhagen 2020 Synthesis of the character impact compound raspberry ketone and additional flavoring phenylbutanoids of biotechnological interest with Corynebacterium glutamicum Microb Cell Fact 1992 https://doi.org/10.1186/s12934-020-01351-y

121. D Burschowsky HV Thorbjørnsrud JB Heim JR Fahrig-Kamarauskaite K Würth-Roderer P Kast U Krengel 2018 Inter-Enzyme allosteric regulation of chorismate mutase in Corynebacterium glutamicum: structural basis of feedback activation by Trp Biochemistry 57557573 https://doi.org/ 10.1021/acs.biochem.7b01018

122. M Si C Chen Z Wei Z Gong G Li S Yao 2019 CarR, a MarR-family regulator from Corynebacterium glutamicum, modulated antibiotic and aromatic compound resistance Biochem J 47631413159 https://doi.org/10. 1042/BCJ20190320

123. Yu Wang H Cheng Y Liu Ye Liu X Wen K Zhang 2021 In-situ generation of large numbers of genetic combinations for metabolic reprogramming via CRISPR-guided base editing Nat Commun 12112 https://doi. org/10.1038/s41467-021-21003-y

124. Y Yang G Liu X Chen M Liu C Zhan X Liu Z Bai 2020 High efficiency CRISPR/Cas9 genome editing system with an eliminable episomal sgRNA plasmid in Pichia pastoris Enzyme Microb Technol https://doi. org/10.1016/j.enzmictec.2020.109556
125. R Kent N Dixon 2019 Systematic evaluation of genetic and environmental factors affecting performance of translational riboswitches ACS Synth Biol 8884901 https://doi.org/10.1021/acssynbio.9b00017

126. S Jurischka A Bida D Dohmen-Olma B Kleine J Potzkei S Binder 2020 A secretion biosensor for monitoring Sec-dependent protein export in Corynebacterium g/utamicum Microb Cell Fact 1911 https://doi.org/10. 1186/s12934-019-1273-z

127. Imao K, Konishi R, Kishida M, Hirata Y, Segawa S, Adachi N, et al (2017) 1,5-Diaminopentane production from xylooligosaccharides using metabolically engineered Corynebacterium glutamicum displaying beta-xylosidase on the cell surface. Bioresour Technol 24516841691

\section{Publisher's Note}

Springer Nature remains neutral with regard to jurisdictional claims in published maps and institutional affiliations.
Ready to submit your research? Choose BMC and benefit from:

- fast, convenient online submission

- thorough peer review by experienced researchers in your field

- rapid publication on acceptance

- support for research data, including large and complex data types

- gold Open Access which fosters wider collaboration and increased citations

- maximum visibility for your research: over $100 \mathrm{M}$ website views per year

At BMC, research is always in progress.

Learn more biomedcentral.com/submissions 